\title{
Foramina Parietalia Permagna in a Nigerian Family
}

\author{
Foramina Parietalia Permagna dans une Famille nigériane
}

\author{
T. O. Bello*†, A. A. Bajomo ${ }^{\ddagger}$ T. O. Adeniyi ${ }^{\dagger}$
}

\begin{abstract}
BACKGROUND: Enlarged parietal foramina are defects in the skull and are believed to be benign and familial and caused by variable degree of defective intramembranous ossification of the parietal bones. They are rare and asymptomatic, usually associated with $A L X 4$ or $M S X 2$ gene mutations and transmitted as autosomal dominant.

OBJECTIVE: To highlight the importance of plain radiographs in the diagnosis of this condition and need for health education in affected families.

METHODS: Afour-year old male presented with a 14-day history of fever, seizures, and loss of consciousness. Full clinical and radiological evaluation was undertaken.

RESULTS: Physical examination showed an unconscious boy who was having persistent twitching of the upper limbs. Investigations of skull $\mathrm{X}$-rays which showed bilateral parasagital lucencies in the parietal bones. Ultrasound scan showed a mass in the posterior fourth ventricle. The father admitted to having defects in his skull. The patient's elder brother also had defects in his skull.

CONCLUSION: The case illustrates that PFM is usually benign and mostly discovered accidently. In most cases, health education and reassurance are all that are necessary. WAJM 2009; 28(3): 182-184.
\end{abstract}

Key words: Congenital parietal foramina, skull defects, brain ultrasonography.

\section{RÉSUMÉ}

CONTEXTE: parietal Élargis foramina sont des défauts dans le crâne et sont crus être bienveillants et familiaux et provoqués(causés) par le niveau variable d'ossification intramembraneuse défectueuse des os parietal. Ils sont rares et asymptomatic, d'habitude associé à ALX4 ou à mutations de gène MSX2 et transmis comme autosomal dominant.

OBJECTIF: accentuer l'importance de radiographies simples dans le diagnostic de cette condition et de besoin pour l'éducation sanitaire dans les familles affectées.

MÉTHODES: un mâle de quatre ans présenté avec une histoire de 14 jours de fièvre, saisies et perte de conscience. La pleine évaluation clinique et radiologique a été entreprise.

RÉSULTATS: l'examen physique a montré à un garçon évanoui qui avait le tic persistant des membres supérieurs. Les enquêtes de rayons $X$ de crâne qui ont montré parasagital bilatéral lucencies dans les os parietal. Le scanner d'ultrasons a montré une masse dans le quatrième ventricule postérieur. Le père a avoué avoir des défauts dans son crâne. Le frère â̂né du patient avait aussi des défauts dans son crâne.

CONCLUSION: le cas l'illustre PFM est accidently d'habitude bienveillant et surtout découvert. Dans la plupart des cas, l'éducation sanitaire et le réconfort sont tous font de la dentelle est nécessaire. WAJM 2009; 28(3): 182-184.

Mots clé: parietal congénital foramina, défauts de crâne, échographie du cerveau,

Departments of ${ }^{*}$ Radiology, LAUTECH College of Health Sciences, Osogbo, Radiology, Olabisi Onabanjo University Teaching hospital, Sagamu, Ogun State, Nigeria,

*Correspondence: Dr Bello T.O, Department of Radiology, LAUTECH College of Health Sciences, PMB 4400, Osogbo, Osun State, Nigeria. Email: topebello@gmail.com

Abbreviations: CT, Computed tomography; PFM, Parietal foramina; MRI, Magnetic resonance imaging. 


\section{INTRODUCTION}

Enlarged parietal foramina (PFM), also called congenital parietal foramina are defects of the human skull vault, characterised by symmetrical, oval defects in the parietal bone located on each side of the sagittal suture. The defect is thought to be a normal variant of skull development and consequently a benign entity. It is usually asymptomatic and caused by deficient ossification around the parietal notch that is normally obliterated by the fifth month of foetal development. ${ }^{1}$ Isolated enlarged parietal foramina are caused by ALX4 or MSX2 gene mutations and are usually primary osseous defects. However, PFM is sometimes associated with some severe genetic diseases such as Cleidocranial dysplasia and SaethreChotzen syndrome. ${ }^{2,3}$

We report a case of parietal foramina in three generations of males in a Nigerian family.

\section{Case Report}

A four-year old boy presented with a 14-day history of fever and loss of consciousness and seizure. The child was fully examined and investigated including skull x-rays.

\section{Findings}

The patient was unconscious, hypotonic and had a left facial nerve palsy, with persistent twitching of the upper limbs.

The differential diagnosis included

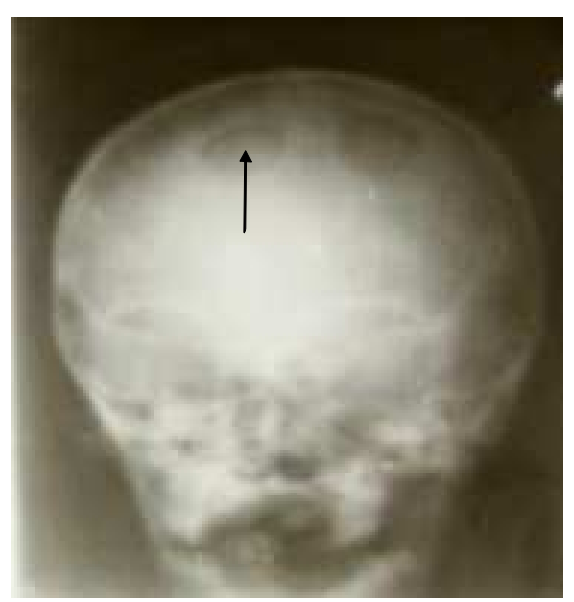

Fig. 1: Note the presence of bilateral parasagital ovoid lucencies in the posterior part of the parietal bone with well defined margins. These are typical of parietal foramina. intracranial neoplasm, meningitis or cerebral malaria. The cerebrospinal fluid examination was within normal limits, full blood count was normal, 2+ malaria parasites in the blood film. Patient was treated for malaria and placed on intravenous fluids.

A skull radiograph was requested, radiograph was normal except for the presence of bilateral parasagital ovoid lucencies in the posterior part of the parietal bone, with well defined margins in keeping with enlarged parietal foramina. (Fig. 1). On further questioning, the father revealed he also had defects in his skull, and that similar defects are present in the first child and paternal grandfather.

Ultrasound examination of the brain showed dilatation of the lateral ventricle and a mass posterior to the fourth ventricle. The patient was lost before fourth intervention could be carried out.

Genetic studies and CT evaluation could not be done. Using the parietal foramina as an acoustic window, we did an ultrasound examination of the brain (Fig. 2). We were able to demonstrate dilatation of the lateral ventricles and also visualize a mass posterior to the fourth ventricle. The patient condition became worse, and we lost the patient three weeks into admission. The parents refused an autopsy.

\section{Comments}

Parietal Foramen is usually diagnosed as an incident finding, as illustrated in this case. The skull radiograph was requested primarily to exclude space occupying lesion, $\mathrm{CT}$ and MRI are the gold standard in assessing intracranial masses. Most cases of PFM are asymptomatic but it has been shown to be associated with neuro-logical symptoms. A case associated with epilepsy and polymicrogyria was reported by Valente $e t a l .{ }^{4}$ Most patients diagnosed with enlarged parietal foramina usually have an affected parent. ${ }^{5}$

Unfortunately, in this patient we could not confirm the presence of an intracranial tumour because of the nonavailability of computerised tomography or magnetic resonance imaging machines. This would have assisted in making a definitive diagnosis and more importantly for better clinical care of the patient.
Ultrasonography which revealed dilatation of lateral ventricles and mass in the posterior fossa was possible due to the PFM, but it has a low specificity and sensitivity in the detection of brain tumours. Giant parietal foramina have been detected occasionally on antenatal sonography in the mid-trimester ${ }^{6}$. Imaging the posterior fossa was difficult in this patient with ultrasonography a problem that could have been solved easily with magnetic resonance imaging or computerised tomography brain ultrasonography is not a substitute for neuro-imaging with $\mathrm{CT}$ or MRI in the diagnosis of brain tumours. ${ }^{7}$

A lot has been written in the western world concerning the autosomal dominant mode of inheritance of Parietal foramina; the penetrance has been reported as $90 \% 5$, in this report three generations of males had PFM.

Isolated enlarged parietal foramina need to be distinguished from other causes of defective skull ossification, for example, meningoencephalocele, ventricular or arachnoid cyst, ectopic glial tissue, tumours, scalp defects, craniolacunae, osteoporosis, localised inflammation, injury and infections.

The role of surgery in the treatment of PFM is controversial because parietal foramina usually decrease in size as patients gets older, although some surgeons have suggested surgical closure of the defect. Most doctors are of the opinion that treatment should be conservative, and advocate that health education for the patient and family is all that is necessary. ${ }^{8}$

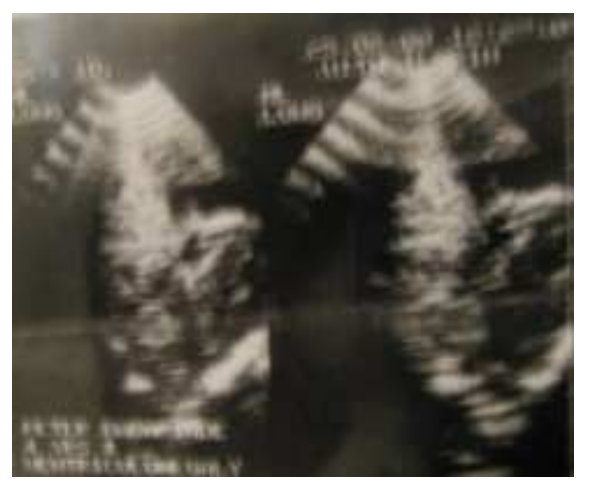

Fig. 2: Ultrasound scan of the brain of the patient using the parietalia foramina as an acoustic window. Note the dilatations of the lateral ventricle and also a mass posterior to the fourth ventricle. 


\section{REFERENCES}

1. Currarino G. Normal variants and congenital anomalies in the region of the obelion. American J Roentgenology 1976; 127: 487-94.

2. Meijlink F, Beverdam A, Brouwer A, Oosterveen TC, Ten Berge D.Vertebrate aristaless-related genes. Int J Dev Biol 1999; 43: 651-663.

3. Lampros A Mavrogiannis, Indira B Taylor, Sally J Davies, Feliciano J Ramos, Jose' L Olivares, and Andrew OM Wilkie. Enlarged parietal foramina caused by mutations in the homeobox genes ALX4 and MSX2: from genotype to phenotype. European Journal of Human Genetics 2006; 14: 151-158.

4. K D Valente, M Valente. Epilepsy in one family with parietal foramina: an incidental finding? Journal of Neurology Neurosurgery and Psychiatry 2004; 75: 1648-1649.

5. Wuyts W, Reardon W, Preis S. et al. Identification of mutations in the MSX2 homeobox gene in families affected with foramina parietalia permagna. Human Molecular Genetics 2000; 9: 1251-1255
6. Fernandez G, Hertzberg BS. Prenatal sonographic detection of giant parietal foramina. J Ultrasound Med 1992; 11: 155-57.

7. A.M. Fink and W. Maixner: Enlarged Parietal Foramina: MR Imaging Features in the Fetus and Neonate. American Journal of Neuroradiology 2006: 1379_ 1381.

8. Kortesis B, Richards T, David L, Glazier S, Argenta L, Surgical management of foramina parietalia permagna. $J$ Craniofacial Surgery 2003; 14: 538544. 